\title{
PEMETAAN POTENSI AIR TANAH DI KECAMATAN CEMPAKA MENGGUNAKAN METODE GEOLISTRIK TAHANAN JENIS KONFIGURASI SCHLUMBERG (1DVES)
}

\author{
WATER POTENTIALS MAPPING IN CEMPAKA DISTRICT USING GEOLISTRIC METHOD \\ RESISTANCE TYPE OF SCHLUMBERG CONFIGURATION (IDVES)
}

\author{
Dicky Audi Rahman, Rony Riduan, Ninis Hadi Harvanti \\ Program Studi Teknik Lingkungan, Fakultas Teknik, Universitas Lambung Mangkurat, Jl. Jend. A. \\ Yani Km 36, Banjarbaru, Kalimantan Selatan, 70714, Indonesia. \\ Email:Dickyaudi.rahman@gmail.com
}

\begin{abstract}
ABSTRAK
Air tanah mempunyai peranan sangat penting terutama dalam menjaga keseimbangan dan ketersediaan bahan baku air untuk kepentingan rumah tangga (domestik) maupun untuk kepentingan non domestic. Semakin berkembangnya industri dan permukiman menimbulkan permasalahan dalam pemenuhan air bersih di Kecamatan Cempaka khususnya Kelurahan Bangkal dan Kelurahan Bangkal disertai adanya daerah rawan air. Berdasarkan permasalahan yang ada maka dilakukan pemetaan potensi air tanah guna mengetahui adanya keberadaan air tanah untuk kebutuhan air bersih. Metode yang digunakan adalah metode geolistrik tahanan jenis konfigurasi schlumberg. Berdasarkan hasil pengukuran dan pengolahan data didapatkan nilai kedalaman dan ketebalan yang bervariasi. Titik 1 Palam (80-124m; 30m), Titik 2 Palam (36-86m; 50m), Titik 3 Palam (44-65m; 21m), Titik 4 Palam (9.5-12.5m; 3m), Titik 1 Bangkal (125-185m; 60m), Titik 2 Bangkal (24 - 40m; 16m), Titik 3 Bangkal (62.5 - 102.5m; 40m) dan Titik 4 Bangkal (5.94 - 35m; 29.06m). Sehingga kriteria potensi air tanah di Titik 1 Palam (Besar), Titik 2 Palam (Besar), Titik 3 Palam (Besar), Titik 4 Palam (Kecil), Titik 1 Bangkal (Besar), Titik 2 Bangkal (Sedang), Titik 3 Bangkal (Besar) dan Titik 4 Bangkal (Besar).
\end{abstract}

Kata kunci: potensi air tanah, kedalaman lapisan tanah, ketebalan lapisan tanah

\section{ABSTRACT}

The ground water has a very important role in maintaining the balance and existance of water materials for household (domestic) or non domestic. The development of industries and residential cause the problems in the fulfillment of clean water in the District of Cempaka especially Bangkal Village and Bangkal Village accompanied by water-prone areas. Based on these problems, therefore it is necessary to mapping of potential ground water to determine the presence of ground water to clean water requirement. The method used is geolistric method resistance type of schlumberger configuration. Based on the results of measurement and data processing the values of depth and thickness vary. Point 1 Palam (80-124m; 30m), point 2 Palam (36-86m; 50M), point 3 Palam (44 - 65m; 21m), point 4 Palam (9.5 - 12.5m; 3m), point 1 Bangkal (125 - 185m, 60m), Point 2 Bangkal 
(24 - 40m; 16m), Point 3 Bangkal (62.5 - 102.5m; 40m) and Point 4 Bangkal (5.94 - 35m; 29.06m). So the criteria of ground water potential in Point 1 Palam (Large), Point 2 Palam (Large), Point 3 Palam (Large), Point 4 Palam (Small), Point 1 Bangkal (Large), Point 2 Bangkal ( Medium), Point 3 Bangkal (Large) and point 4 Bangkal (Large).

Keywords: ground water potential, depth of soil layer, thickness of soil layer

\section{PENDAHULUAN}

Kota Banjarbaru merupakan kota administratif yang memilik lima wilayah kecamatan salah satunya Kecamatan Cempaka. Menurut BPS (2015) secara geografis Kecamatan Cempaka berada pada posisi $233^{\circ} 27^{\prime} \mathrm{LS}$ dan $114^{\circ} 45^{\prime} \mathrm{BT}$. Kecamatan Cempaka sebagai sub pusat kota memiliki wilayah dengan luas $\pm 14.670 \mathrm{Ha}(39,50 \%$ dari wilayah Kota Banjarbaru), yang terbagi menjadi empat kelurahan yaitu Kelurahan Palam, Kelurahan Bangkal, Kelurahan Sungai Tiung dan Kelurahan Cempaka. Kecematan Cempaka memilik jumlah penduduk sebesar 32.075 orang, untuk memenuhi kebutuhan air bersih Kecamatan Cempaka, sebagian besar masyarakat disana menggunakan sumur bor maupun sumur gali daripada jaringan perpipaan yang dilayani PDAM Intan Banjar (Dinas PU Banjarbaru, 2015). Hal ini dikarenakan jarak antara instalasi pengolahan ke rumah warga yang ada di Kecamatan Cempaka sangat jauh dan fasilitas untuk mendukung pemasangan perpipaan memerlukan biaya cukup besar. Namun penggunaan sumur bor ataupun sumur gali kurang optimal dalam pemenuhan kebutuhan air bersih karena sering terjadi kekeringan yang menimbulkan permasalahan pada pemenuhan air bersih. Berdasarkan data cakupan pelayanan Dinas PU Kota Banjarbaru (2015) cakupan pelayanan kebutuhan air bersih di Kelurahan Palam dan Kelurahan Bangkal sebesar 0,69\% dari 8.524 jiwa di dua kelurahan tersebut. Permasalahan dalam pemenuhan air bersih di Kecamatan Cempaka juga diperkuat dengan adanya daerah rawan air di Kelurahan Bangkal dan Kelurahan palam yang membuat masyarakat daerah tersebut sangat kekurangan air bersih.

Berdasarkan data kondisi daerah rawan air Dinas PU Kota Banjarbaru (2015) menunjukan daerah rawan air Kota Banjarbaru meliputi Kelurahan Cempaka, Kelurahan Bangkal, Kelurahan Palam dan Kelurahan Landasan Ulin Selatan. Hal ini menjadikan pemerintah daerah Kota Banjarbaru mencari solusi dengan menjalankan suatu program Rencana Pembangunan Jangka Menengah Nasional (RPJMN) 2015-2019 untuk mengembangkan sistem penyediaan air minum dengan harapan cakupan pemenuhan kebutuhan air minum 100\% pada tahun 2019 (universal access). Selain itu perlu adanya penelitian lebih lanjut terhadap masalah daerah rawan air dengan melakukan penyelidikan melalui permukaan tanah atau bawah tanah menggunakan metode geolistrik tahanan jenis konfigurasi schlumberger.

\section{METODELOGI PENELITIAN}

\section{Lokasi dan Waktu}

Penelitian ini dilakukan di Kecamatan Cempaka pada dua Kelurahan, yaitu Kelurahan Bangkal, dan Kelurahan Palam yang merupakan daerah rawan air. Penelitian ini juga dilakukan selama 2 hari (Gambar 1). 


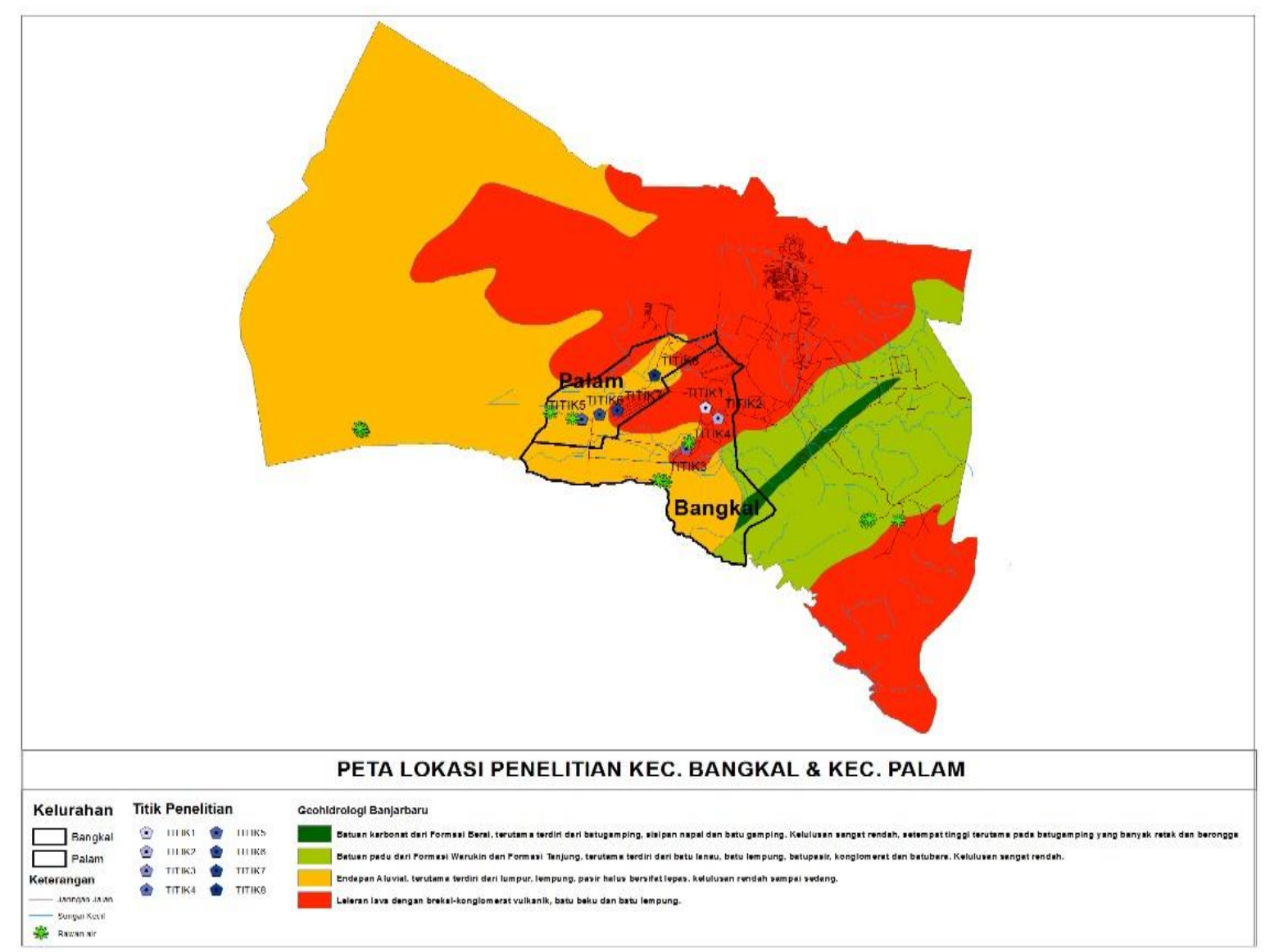

Gambar 1 Peta lokasi Penelitian

Untuk titik potensi air tanah jumlah titik yang diambil sebanyak 4 titik pada 2 zona formasi batuan di kelurahan palam dan 4 titik pada 2 zona formasi batuan di Kelurahan Bangkal.

\section{Alat dan Bahan}

Alat dan bahan yang digunakan pada penelitian ini yaitu: (1) Resistivitymeter Merk Noniura NRD $300 \mathrm{HF}$, (2) Elektroda sebanyak 4 buah, (3) Jepitan kabel penghubung sebanyak 4 buah, (4) Kabel penghubung dengan panjang 600 meter sebanyak 2 buah, (5) Rollmeter sepanjang 200 meter sebanyak 4 buah, (6) Accu $12 \mathrm{~V}$ sebanyak 1 buah, (7) GPS (Global Positioning System), (8) HT (Hand Talky) sebanyak 4 buah, (9) Laptop, (10) Alat tulis.

\section{Metode Pengukuran dan Interpretasi Data Geolistrik}

Metode penelitian yang digunakan mengacu pada metode geolistrik tahanan jenis konfigurasi schlumberg, yaitu salah satu metode geofisika yang biasa digunakan untuk penyelidikan bawah permukaan dengan memanfaatkan sifat aliran listrik di dalam permukaan bumi. Metode ini meliputi pengukuran beda potensial dan arus listrik yang terjadi akibat injeksi arus listrik ke dalam bumi melalui sepasang elektroda arus. Perbedaan potensial diukur melalui sepasang elektroda potensial (Sigit dkk., 2014). Untuk aturan elektroda schlumberger, spasi elektroda arus jauh lebih besar daripada spasi elektroda potensial. Secara garis besar aturan elektroda dilihat pada Gambar 2. 


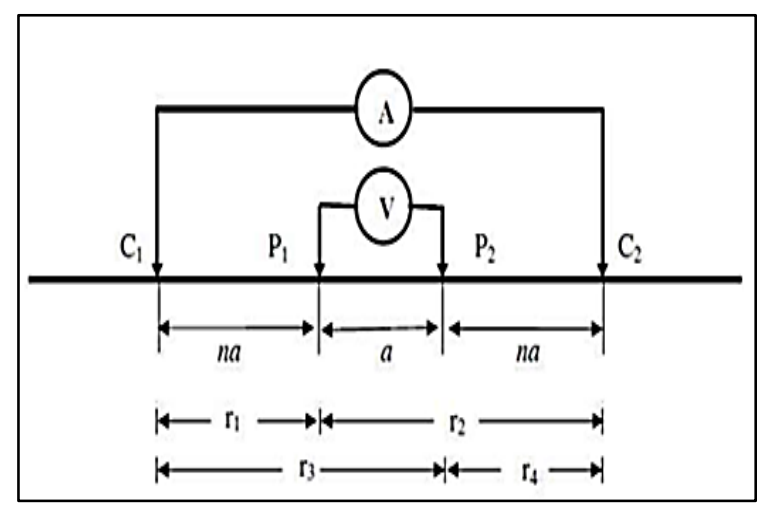

Gambar 2 Aturan Konfigurasi Schlumberg (Sukur, 2015)

Untuk mendapatkan nilai tahanan jenis maka persamaan yang digunakan mengacu pada aturan schlumberg. Setelah nilai tahanan jenis dihitumg, maka dapat diketahui susunan batuan berdasarkan nilai tahanan jenis tersebut. Penentuan susunan batuan didasarkan pada Tabel 1.

Tabel 1 Resistivitas batuan dan fluida

\begin{tabular}{lc}
\hline \multicolumn{1}{c}{ Jenis Tanah/ Batuan } & Resistivity $(\mathbf{\Omega m})$ \\
\hline Tanah Lempung, basah lembek & $1,5-3,0$ \\
Tanah Lanau \& tanah lanau basah lembek & $3-15$ \\
Tanah lanau, pasiran & $15-150$ \\
Batuan dasar berkekartersi tanah lembab & $150-300$ \\
Pasir kerikil terdapat lapisan lanau & \pm 300 \\
Batuan dasar terisi tanah kering & $300-2400$ \\
Batuan dasar tak lapuk & 2400 \\
\hline
\end{tabular}

Sumber : Roy (1984)

Dalam tahap interpretasi data tahanan jenis dilakukan berupa penampang 1 dimensi menggunakan software Progres 3.0 dan penampang 3 dimensi dengan menggunakan software Surfer 11. Pada tahapan ini hasil output yang dihasilkan oleh software Surfer akan menampilkan gambar penampang vertikal dan horisontal. Dari perbedaan nilai tahanan jenis inilah kita dapat menafsirkan kondisi dibawah permukaan lapisan tanah yang mempunyai kandungan air untuk digunakan sebagai kebutuhan sehari-hari.

\section{HASIL DAN PEMBAHASAN}

Pada penelitian ini dilakukan di dua lokasi yang berbeda yang berada di Kelurahan Palam dan Kelurahan Bangkal. Di setiap lokasi tersebut diambil empat buah titik yang masing masing mewakili jenis tanah didaerah tersebut. Setiap titik memiliki panjang lintasan yang sama yaitu 300 meter, dimana lintasan disisi sebelah kiri dan sebelah kanan mempunyai bentangan sebesar 150 meter dengan 29 titik pengukuran dan spasi yang berbeda-beda mulai dari 1 meter-300 meter. Penelitian ini mengenai model lapisan tanah menggunakan metode tahanan jenis konfigurasi schlumberger.

Hasil data yang diperoleh dari hasil pengukuran dilapangan ini diolah dengan menggunakan software Progres 3.0 dan Surfer 11. Pada pengolahan data menggunakan software Progres 3.0 didapatkan penempang secara 1 dimensi dengan kedalaman maksimal 200 meter. Pada software ini diperoleh hasil berupa grafik log dan tabel hubungan antara nilai tahanan jenis dengan kedalaman dalam bentuk 1 dimensi. 
Pada pengolahan data kali ini hanya titik pertama saja yang ditampilkan sedangkan untuk tujuh titik lainnya akan ditampilkan melalui analisis pengukuran dan batuan. Berikut hasil pengolahan data menggunakan software Progres 3.0 ditunjukkan pada Gambar 3.

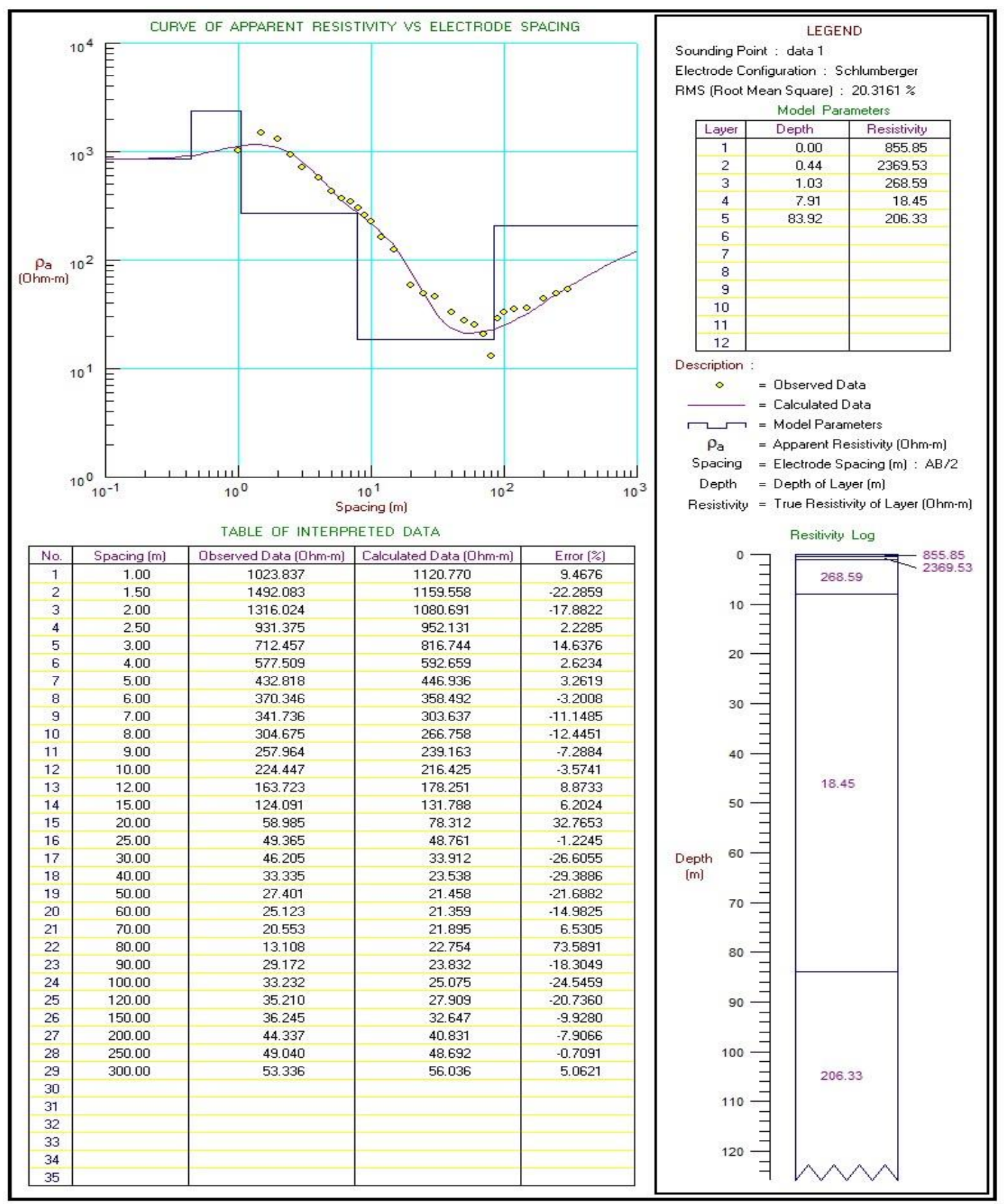

Gambar 3 Kurva Hubungan antara Nilai resistivitas dengan Jarak Elektroda

Berdasarkan hasil pengolahan data tahanan jenis menggunakan software Progres 3.0 dan berdasarkan peta geologi daerah penelitian, pada pengukuran di titik pertama ini dapat dikelompokan jenis-jenis batuan bedasarkan nilai resistivitas di daerah penelitian sebagaimana pada Tabel 2.

Tabel 2 Jenis Batuan Berdasarkan Resistivitas Titik Pertama 


\begin{tabular}{ccc}
\hline Nilai Resistivitas $(\boldsymbol{\Omega m})$ & Jeins Batuan & Kedalaman $(\mathbf{m})$ \\
\hline 2369,53 & Batuan beku & $0-0,44$ \\
268,59 & Batuan lempung & $1,03-8,00$ \\
18,45 & Tanah lanau lembek & $8,00-83,00$ \\
83,92 & Tanah pasir, banyak & $84,00-124$ \\
\hline
\end{tabular}

Berdasarkan hasil pengolahan data 1 dimensi dengan menggunakan software Progres 3.0 didapatkan model geolistrik tahanan jenis yang hasil kedalaman air tanah dapat diketahui beserta jenis batuan sesuai peta geologi di lokasi tersebut. Air tanah diprediksi berada pada kedalaman $84-124$ m pada titik pertama pengukuran $\mathrm{Hal}$ ini ditandai pada lapisan pasir yang memiliki rentang nilai resistivitas $42-180 \Omega \mathrm{m}$. Semakin tebal lapisan yang mengandung air tanah, maka potensinya semakin besar (Eke dkk, 2011; Anton dkk, 2014). Namun potensi air tanah tidak hanya ditinjau dari ketebalan lapisan saja, ada faktor lain seperti luas area, kemudahan untuk dieksploitasi dan lain-lain.

\section{Analisis Pengukuran dan Analisis Batuan}

Pengukuran menggunakan metode geolistrik tahanan jenis konfigurasi Schlumberg dengan titik pengukuran sebanyak delapan titik di dua kelurahan yaitu Kelurahan Palam dan Kelurahan Bangkal. Berikut ini Hasil Pengukuran nilai resistivitas beserta jenis batuan pada Tabel 3.

Tabel 3 Hasil Pengukuran Nilai Tahanan Jenis beserta Jenis Batuan di 8 Titik Pengukuran

\begin{tabular}{|c|c|c|c|c|}
\hline $\begin{array}{c}\text { Nilai } \\
\text { Resistivitas } \\
(\Omega \mathrm{m})\end{array}$ & Jeins Batuan & $\begin{array}{l}\text { Kedalaman } \\
(\mathbf{m})\end{array}$ & $\begin{array}{l}\text { Ketebalan } \\
\quad(\mathbf{m})\end{array}$ & Lokasi \\
\hline 83,92 & $\begin{array}{l}\text { Tanah pasir, banyak } \\
\text { mengandung tanah }\end{array}$ & $84,00-124$ & 30 & Titik 1 palam \\
\hline 85,42 & $\begin{array}{l}\text { Tanah pasir, } \\
\text { menandung banyak } \\
\text { air tanah }\end{array}$ & $36-86$ & 50 & Titik 2 palam \\
\hline 102,17 & $\begin{array}{l}\text { Tanah pasir halus, } \\
\text { banyak mengandung } \\
\text { air tanah }\end{array}$ & $44-65$ & 21 & Titik 3 palam \\
\hline 170,39 & $\begin{array}{l}\text { Tanah pasiran, cukup } \\
\text { mengandung air } \\
\text { tanah }\end{array}$ & $9,5-12,5$ & 3 & Titik 4 palam \\
\hline 141,74 & $\begin{array}{l}\text { Tanah pasir, banyak } \\
\text { mengandung air } \\
\text { tanah }\end{array}$ & $125-185$ & 60 & Titik 1 bangkal \\
\hline 165,10 & $\begin{array}{l}\text { Tanah pasir, banyak } \\
\text { mengandung air } \\
\text { tanah }\end{array}$ & $24-40$ & 16 & Titik 2 bangkal \\
\hline 179,08 & $\begin{array}{l}\text { Tanah pasir, banyak } \\
\text { mengandung air } \\
\text { tanah }\end{array}$ & $62,5-102,5$ & 40 & Titik bangkal \\
\hline 42,72 & Tanah lanau pasiran & $5,94-35$ & 29,06 & Titik 4 bangkal \\
\hline
\end{tabular}




\section{Pemetaan Potensi Air Tanah}

Setelah dilakukan pengambilan data resistivitas dan diolah menggunakan Software Progres 3.0 maka didapatkan keberadaan air tanah yang digunakan untuk sumber air bersih. Data tersebut di peroleh berupa kedalaman lapisan dan jenis batuan yang mengandung air tanah. Selanjutnya data tersebut di tampilkan dalam bentuk peta kontur persebaran air tanah di delapan lokasi titik penelitian yang pada Gambar 4 dan Gambar 5.

\section{PETA SEBARAN POTENSI AIR TANAH KELURAHAN BANGKAL \& KELURAHAN PALAM}
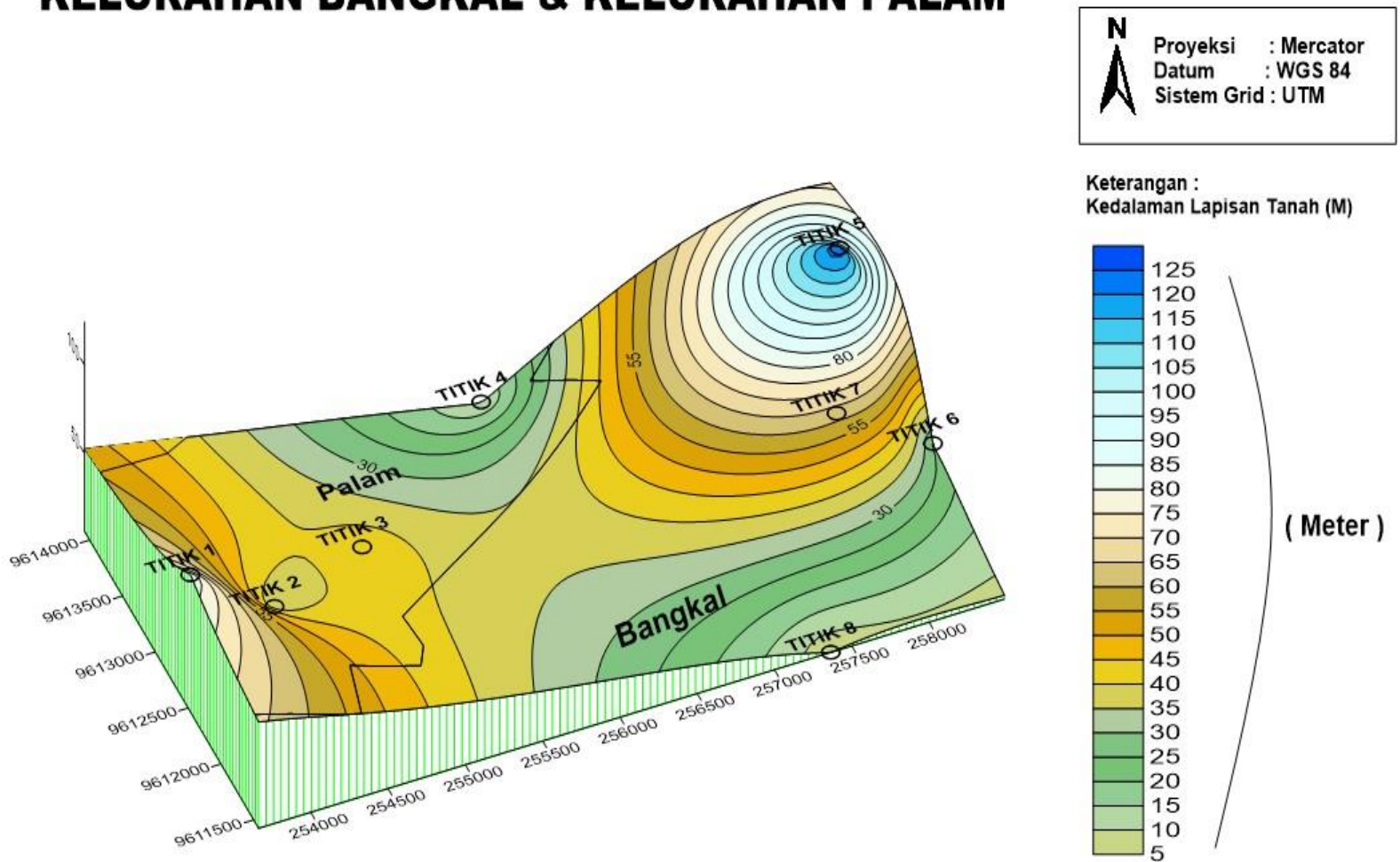

Keterangan :

Kedalaman Lapisan Tanah (M)

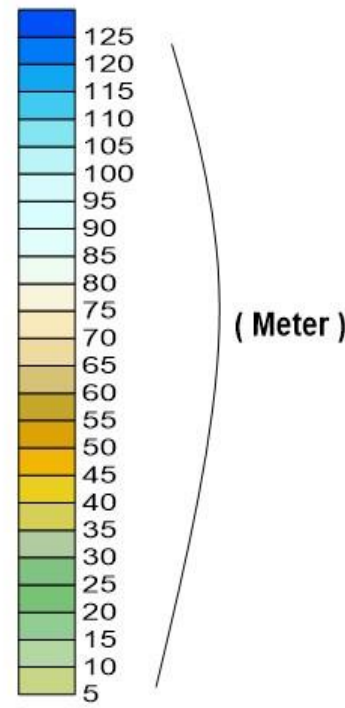

Dibuat Oleh:

DICKY AUDI RAHMAN (H1E113043)

Sumber :

1. Google Earth Pro 2017

2. Peta Analisis Perhitungan 2017

Gambar 4 Peta 3D Sebaran Kedalaman Potensi Air Tanah 

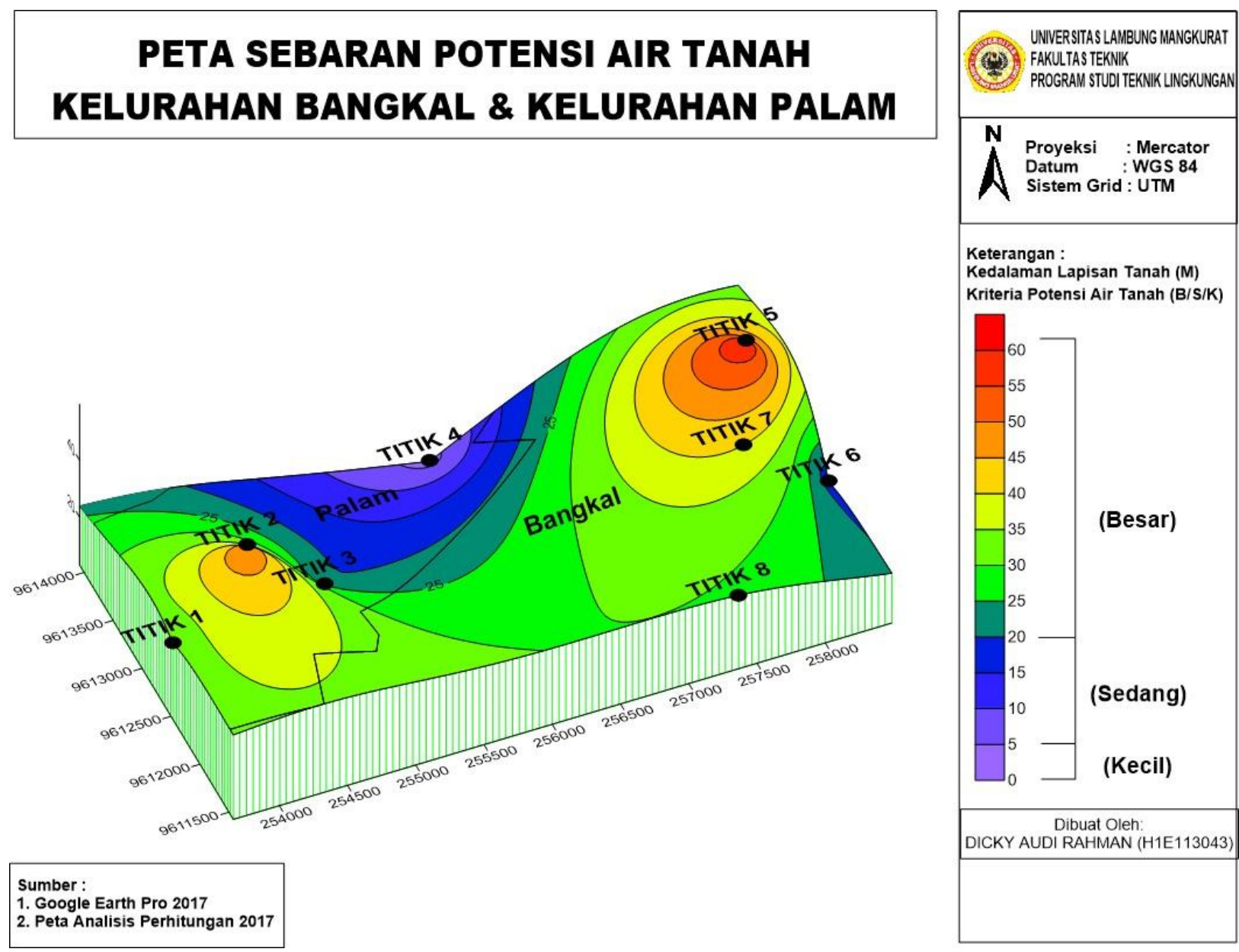

Gambar 5 Peta 3D Sebaran Ketebalan Potensi Air Tanah

Dari hasil pengolahan data tahanan jenis menggunakan software surfer diperoleh peta kontur sebaran potensi air tanah dengan kedalaman dan ketebalan di setiap titik penelitian yang bervariasi sehingga dapat dipredeksi besaran potensi air tanah di setiap tersebut. Potensi air tanah dikelompokan menjadi tiga kelas yaitu potensi besar yang mengandung air tanah dengan ketebalan lapisan diatas 20 meter. Potensi sedang yang mengandung air tanah dengan ketebalan diatas antara 5 - 20 meter, sedangkan potensi kecil yang mengandung air tanah dengan ketebalan dibawah 5 meter. Penggolongan dalam potensi air tanah ini relatif, artinya berdasarkan jumlah penduduk didaerah penelitian (Anton dkk, 2014). Berikut ini tabel tingkat potensi air tanah yang ditunjukan pada Tabel 4.

Tabel 4. Tingkat potensi air tanah

\begin{tabular}{clcccc}
\hline $\begin{array}{c}\text { Nilai } \\
\text { Resistivitas } \\
(\boldsymbol{\Omega} \mathbf{m})\end{array}$ & Jeins Batuan & $\begin{array}{c}\text { Kedalaman } \\
(\mathbf{m})\end{array}$ & $\begin{array}{c}\text { Ketebalan } \\
(\mathbf{m})\end{array}$ & Lokasi & Kriteria \\
\hline 83,92 & $\begin{array}{l}\text { Tanah pasir, } \\
\text { banyak } \\
\text { mengandung tanah } \\
\text { Tanah pasir, } \\
\text { menandung banyak } \\
\text { air tanah } \\
\text { Tanah pasir halus, } \\
\text { banyak }\end{array}$ & 46-124 & 30 & Titik 1 palam & Besar \\
102,17 & 50 & Titik 2 palam & Besar \\
\hline
\end{tabular}




\begin{tabular}{|c|c|c|c|c|c|}
\hline $\begin{array}{c}\text { Nilai } \\
\text { Resistivitas } \\
(\Omega \mathrm{m})\end{array}$ & Jeins Batuan & $\begin{array}{l}\text { Kedalaman } \\
\quad(\mathbf{m})\end{array}$ & $\begin{array}{l}\text { Ketebalan } \\
\quad(\mathbf{m})\end{array}$ & Lokasi & Kriteria \\
\hline & $\begin{array}{ll}\text { mengandung air } \\
\text { tanah }\end{array}$ & & & & \\
\hline 170,39 & $\begin{array}{l}\text { Tanah pasiran, } \\
\text { cukup mengandung } \\
\text { air tanah }\end{array}$ & $9,5-12,5$ & 3 & Titik 4 palam & Kecil \\
\hline 141,74 & $\begin{array}{l}\text { Tanah } \\
\text { banyak } \\
\text { mengandung } \\
\text { tanah }\end{array}$ & $125-185$ & 60 & Titik 1 bangkal & Besar \\
\hline 165,10 & $\begin{array}{l}\text { Tanah } \\
\text { banyak } \\
\text { mengandung } \\
\text { tanah }\end{array}$ & $24-40$ & 16 & Titik 2 bangkal & Sedang \\
\hline 179,08 & $\begin{array}{l}\text { Tanah } \\
\text { banyak } \\
\text { mengandung } \\
\text { tanah }\end{array}$ & $62,5-102,5$ & 40 & Titik bangkal & Besar \\
\hline 42,72 & Tanah lanau pasiran & $5,94-35$ & 29,06 & Titik 4 bangkal & \\
\hline
\end{tabular}

\section{KESIMPULAN}

Penyebaran potensi air tanah di delapan titik lokasi penelitian memiliki nilai kedalaman dan ketebalan yang bervariasi. Titik 1 Palam $(80-124 \mathrm{~m}$; 30m), Titik 2 Palam $(36-86 \mathrm{~m}$; 50m), Titik 3 Palam (44 $65 \mathrm{~m} ; 21 \mathrm{~m})$, Titik 4 Palam $(9.5-12.5 \mathrm{~m} ; 3 \mathrm{~m})$, Titik 1 Bangkal (125 - 185m; 60m), Titik 2 Bangkal (24 - 40m; 16m), Titik 3 Bangkal (62.5 - 102.5m; 40m) dan Titik 4 Bangkal (5.94 - 35m; 29.06m). Sehingga dengan nilai tersebut dapat diketahui kriteria potensi air tanah di Titik 1 Palam (Besar), Titik 2 Palam (Besar), Titik 3 Palam (Besar), Titik 4 Palam (Kecil), Titik 1 Bangkal (Besar), Titik 2 Bangkal (Sedang), Titik 3 Bangkal (Besar) dan Titik 4 Bangkal (Besar).

\section{DAFTAR PUSTAKA}

Anonim1. 2015. Dokumen Rencana Induk Sistem Penyediaan Air Minum Kota Banjarbaru 2015. Dinas Pekerjaan Umum Kota Banjarbaru

Anton, K \& Ali, M. (2014). Pemetaan Potensi Air Tanah Sebagai Sumber Air Bersih Daerah Pesisir Pantai Batakan Kabupaten Tanah Laut. Jurnal Teknologi \& Industri. Vol. 3 No. 1. Juni 2014.

Badan, Pusat Statistik. (2015). Kota Banjarbaru Dalam Angka.

Sigit, D., Udi, H. \& Sugeng, W. (2014). Identifikasi Struktur Bawah Permukaan Menggunakan Metode Geolistrik Konfigurasi Schlumberger Di Area Panas Bumi Desa Diwak Dan Derakan Kecamatan Bergas Kabupaten Semarang. Youngster Physic Journal. Vol. 3 No. 2. April 2014. 159-64.

Sukur, K.T. (2015). Struktur Permukaan Tanah Di Kota Lama Semarang Menggunakan Metode Geolistrik Resistivity Konfigurasi Schlumberger. Skripsi. Universitas Negeri Semarang. Semarang 